\title{
Agronomic characteristics and macronutrient export of grain sorghum hybrids from different sowing dates
}

\section{Características agronômicas e exportação de macronutrientes em híbridos de sorgo granífero em diferentes épocas de semeadura}

\author{
César Henrique Souza Zandonadi1 ${ }^{\star}$, Carlos Juliano Brant Albuquerque², Rogério Soares de Freitas ${ }^{3}$, \\ Alyne Dantas Mendes de Paula ${ }^{1}$, Marina Alves Clemente ${ }^{1}$
}

\author{
${ }^{1}$ Universidade Federal de Uberlândia/UFU, Instituto de Ciências Agrárias, Uberlândia, MG, Brasil \\ 2Universidade Federal de Minas Gerais/UFMG, Montes Claros, MG, Brasil \\ ${ }^{3}$ Agência Paulista de Tecnologia Agropecuária/APTA, Votuporanga, SP, Brasi \\ *Corresponding author: cesarzandonadi@yahoo.com.br \\ Received in May 3, 2016 and approved in November 29, 2016
}

\begin{abstract}
Brazilian off-season cropping is increasing the production of cereals, particularly in the Brazilian savannah. Sorghum has been widely used for its grain production capacity and dry matter. Several hybrids are commercially available, each with its own peculiar nutrient absorption capacity. Thus, this study analyzed the agronomic characteristics and nutrient exportation in grain sorghum hybrids sown on different dates. The experiment was conducted at the Paulista Agency Regional Center of Agricultural Technology (APTA) in the city of Votuporanga, São Paulo. The experiment was conducted in a randomized block design with four replications and 4 hybrids. Sorghum hybrids (50A10, 50A50, BUSTER and 1G282) were the different treatments sown on four different dates, beginning with February 26, 2013, with the other dates 17, 30 and 41 days after the first sowing (DAFS). Each sowing date was considered an individual experiment and, subsequently, grouped for analysis to compare characteristics. Macronutrient content in the grain, one thousand grain weight, productivity and exportation of macronutrients $\left(\mathrm{kg} \mathrm{ha}^{-1}\right)$ by grains in the area were evaluated. The productivity of the sorghum hybrids varied depending on the sowing dates. The one thousand grain mass of the sorghum hybrids varied depending on the sowing dates. The average exportation of macronutrients by sorghum grains is as follows, in decreasing order: $\mathrm{N}>\mathrm{K}>\mathrm{P}>\mathrm{Ca}>\mathrm{Mg}>\mathrm{S}$. The mean values of macronutrient accumulation needed to produce one ton of sorghum grains are as follows: $20.05 \mathrm{~kg} \mathrm{~N}, 3.33 \mathrm{~kg}$ P, $3.70 \mathrm{~kg} \mathrm{~K}, 3.49 \mathrm{~kg} \mathrm{Ca}, 1.77 \mathrm{~kg} \mathrm{Mg}$, and $0.72 \mathrm{~kg} \mathrm{~S}$.
\end{abstract}

Index terms: Sorghum bicolor L.; production system; grain; nutrient content.

\begin{abstract}
RESUMO
A produção brasileira na entressafra vem aumentado a cada safra de grãos, principalmente na região do cerrado. O sorgo granífero tem sido bastante utilizado pela sua capacidade de produção de grãos e massa seca nessas condições. Vários são os híbridos disponíveis no mercado, sendo cada um com sua capacidade de absorção de nutrientes. Sendo assim o objetivo desse trabalho foi analisar as características agronômicas e exportação de macronutrientes pelos grãos dos híbridos de sorgo granífero em diferentes épocas de semeadura. 0 experimento foi conduzido no Pólo Regional da Agência Paulista de Tecnologia agropecuária (APTA), no município de Votuporanga, São Paulo. O experimento foi realizado em delineamento de blocos casualizados, com 4 híbridos e quatro repetições. Os híbridos de sorgo (50A10, 50A50, BUSTER e 1G282) constituem os diferentes tratamentos, dentro das quatro diferentes épocas de semeadura, sendo a primeira realizada em 26/02 de 2013 e as demais aos 17, 30 e 41 dias após a primeira semeadura - DAFS. Cada época de semeadura foi considerada como experimento individual, sendo realizada posteriormente a análise conjunta para comparação das características avaliadas. Foram avaliados os teores de macronutrientes nos grãos, massa de mil grãos, produtividade e a exportação desses macronutrientes (kg ha-1) pelos grãos na área. A produtividade dos híbridos de sorgo granífero variam em função das épocas de semeadura. A massa de mil grãos dos híbridos de sorgo granífero variam em função das épocas de semeadura. A exportação média de macronutrientes pelos grãos de sorgo segue a ordem decrescente: $\mathrm{N}>\mathrm{K}>\mathrm{P}>\mathrm{Ca}>\mathrm{Mg}>\mathrm{S}$. Os valores médios de acúmulo de macronutrientes para produção de uma tonelada de grãos de sorgo granífero são: 20,05 kg de N; 3,33 kg de P; 3,70 kg de K; 3,49 kg de Ca; 1,77 kg de Mg e 0,72 kg de $S$.
\end{abstract}

Termos de indexação: Sorghum bicolor L.; sistema de produção; grão; teor de nutrientes.

\section{INTRODUCTION}

Grain sorghum is known for showing better tolerance for water scarcity and a large production of biomass for various uses, which include use of the grain for animal feed or plant cuttings or shoots for grazing animals.
These factors have allowed the expansion of sorghum crops through Brazil, mainly in the off season, in regions with low rainfall and weather conditions that are less favorable to corn cultivation (Parrella et al., 2014; Tolk; Howell; Miller, 2013; Vasconcelos et al., 2001). Even so, in many areas, sorghum production is 
low due to inadequate handling practices and marginal growth conditions, which are primarily caused by low spending on mineral nutrition; many producers believe that grain sorghum is more "rustic" and does not need the phytosanitary treatments that are applied to other crops, which is not the case

Many experiments that have evaluated the productivity of the different grain sorghums have shown the high potential that this crop has for grain production under adverse growing conditions, even in central Brazilian regions (Almeida Filho et al., 2014; Almeida Filho et al., 2010; Silva et al., 2009) or in semiarid regions (Albuquerque et al., 2011).

With the expansion of grain sorghum's production areas and the rising costs of agricultural inputs, labor and equipment, suitable cultivation practices are needed to minimize the negative impacts of agricultural activities and optimize productivity. Productivity is related to many factors, such as good quality genetic material, correct phytosanitary treatments and soil fertility and nutritional supplementation (Fornasieri Filho; Fornasieri, 2009).

Grain sorghum plants are extremely efficient in absorbing nutrients from the ground and have very fibrous and well-developed root systems, which facilitate great fertilization (Leal et al., 2013; Marin et al., 2006).

To determine the fertilizer application needed for the crop to achieve the highest productive potential, we need to know the absorption and accumulation rate of nutrients and the best date for sowing (Santos et al., 2014; Fornasieri Filho; Fornasieri, 2009).

The aim of this work was to evaluate the agronomic features and the macronutrient exportation in grain sorghum hybrids from different sowing dates.

\section{MATERIAL AND METHODS}

The experiments were conducted in the Regional Pole of the Technological Agropecuary Paulista Agence (APTA), in the city of Votuporanga, São Paulo $\left(20^{\circ} 28^{\prime} \mathrm{S}\right.$ and $50^{\circ} 04^{\prime} \mathrm{W}$ ) and at an altitude of $440 \mathrm{~m}$. The ground is characterized as Dusky Red Latosol (oxisol), with a sandy texture and soft relief. The chemical attributes of the soil are shown in Table 1.

According to Prado, Jorge and Menk (1999), the predominant weather in the Votuporanga region is tropical wet and dry or savanna climate (Aw; Köppen), with a definite dry season, an annual average temperature of $22^{\circ} \mathrm{C}$, and a medium temperature range from $18,4{ }^{\circ} \mathrm{C}$ to $23,9^{\circ} \mathrm{C}$. The annual medium rainfall is $1.344 \mathrm{~mm}$, with $74 \%$ of the rain happening from October to March, and $26 \%$ from April to September.

Precipitation and medium temperature during the experimental period are indicated in Figure 1.

In the experiment, 4 sorghum hybrids were used; these hybrids were adapted to the northwest region of São Paulo state. The hybrids used were BUSTER and 50A10, which were developed for early planting, and 1G282 and 50A70, which were developed for late planting. The experiment was conducted in a conventional cultivation system, which required plowing and disking. The sowing and coverage fertilization were the same for all the sowing dates. The sowing fertilization was carried out with $300 \mathrm{~kg} \mathrm{ha}^{-1}$ of the formulated 08-28-16, and the coverage was carried out with $300 \mathrm{~kg} \mathrm{ha}^{-1}$ of ammonium sulfate. The plants received this fertilization in the same phenological stages (5 leaves completed expanded), independently of the sowing date, approximately 18 days after the emergence (Table 2).

The following characteristics were evaluated: one thousand grain mass (g) and productivity $\left(\mathrm{kg} \mathrm{ha}^{-1}\right)$. For this determination, parcels of grain were picked and measured for their humidity, after which the weight was corrected for the grain humidity degree to $13 \%$, according to the formula $\mathrm{Mc}=\{[\mathrm{Mo}(100-\mathrm{u} 0)] / 87\}$; where Mc and Mo were the corrected and observed mass, respectively; $\mathrm{u} 0$ was the observed humidity; and the macronutrients content in the grain is indicated in $\mathrm{g} \mathrm{kg}^{-1}$. Based on the nutrient content and productivity, the exportation of each macronutrient was quantified $\left(\mathrm{kg} \mathrm{ha}^{-1}\right)$.

Table 1: Chemical attributes of the soil in the profile 0-0.2 m, Votuporanga, 2013.

\begin{tabular}{|c|c|c|c|c|c|c|c|c|c|c|c|c|c|}
\hline Camada & $\mathrm{pH} \mathrm{H}_{2} \mathrm{O}$ & $\mathrm{P}$ & $\mathrm{K}$ & $\mathrm{Al}$ & $\mathrm{Ca}$ & $\mathrm{Mg}$ & $\mathrm{H}+\mathrm{Al}$ & SB & $\mathrm{t}$ & $\mathrm{T}$ & V & $\mathrm{m}$ & $\mathrm{MO}$ \\
\hline $\mathrm{m}$ & $(1: 2.5)$ & \multicolumn{2}{|c|}{$\mathrm{mg} \mathrm{dm^{-3 }}$} & 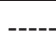 & $\cdots$ & - & nolcd & -- & ----" & & \multicolumn{2}{|c|}{$\%$} & dag $\mathrm{kg}^{-1}$ \\
\hline $0-0.2$ & 5.2 & 30 & 20 & 0 & 17 & 8 & 16 & 25.05 & 25.05 & 41.05 & 61 & 0 & 13 \\
\hline
\end{tabular}

$\mathrm{P}, \mathrm{K}=\left(\mathrm{HCl} 0.05 \mathrm{~mol} \mathrm{~L}^{-1}+\mathrm{H}_{2} \mathrm{SO}_{4} 0.0125 \mathrm{~mol} \mathrm{~L}^{-1}\right) \mathrm{P}$ available (extractor Mehlich-1); $\mathrm{Ca}, \mathrm{Mg}, \mathrm{Al},(\mathrm{KCl} 1 \mathrm{~mol} \mathrm{~L}-1) ; \mathrm{H}+\mathrm{Al}=(\mathrm{Tampon}$ solution - SMP at pH 7.5); SB = Sum of basis; $t=$ cation-exchange capacity (CEC) effective; $T=C E C$ in $p H$ 7.0; $V=S a t u r a t i o n$ for basis; $m$ = Saturation for aluminum (Embrapa, 2009). 


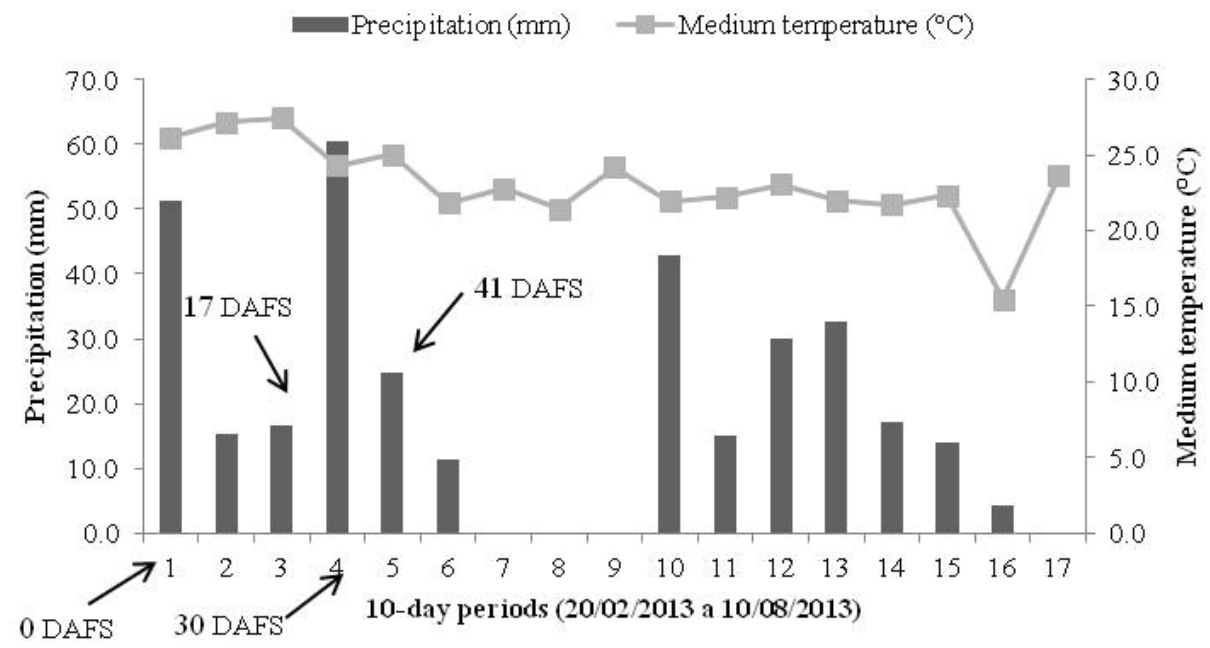

Figure 1: Variation in medium temperature $\left({ }^{\circ} \mathrm{C}\right)$ and accumulated precipitation $(\mathrm{mm})$ for 10 -day periods from February to August 2013 in Votuporanga, SP.

Table 2: Dates of sowing, emergence and coverage fertilization for the different sowings.

\begin{tabular}{ccccc}
\hline Date & Sowing & Days after the first sowing (DAFS) & Emergence & Coverage fertilizaton \\
\hline 1 & $26 / 02 / 2013$ & 0 & $02 / 03 / 2013$ & $20 / 03 / 2013$ \\
2 & $15 / 03 / 2013$ & 17 & $20 / 03 / 2013$ & $09 / 04 / 2013$ \\
3 & $28 / 03 / 2013$ & 30 & $01 / 04 / 2013$ & $18 / 04 / 2013$ \\
4 & $08 / 04 / 2013$ & 41 & $12 / 04 / 2013$ & $30 / 04 / 2013$ \\
\hline
\end{tabular}

Before determination of the nutrient content in the grains, the grains were separated for measurement of the one thousand grain mass. Afterward, the samples were transported to the Earth laboratory in the Federal University of Uberlândia, according to the methods of Malavolta, Vitti and Oliveira (1997). Nitrogen content was determined by the semimicro-Kjeldahl distillation method, and other nutrients were extracted in a nitric-perchloric solution. From the extracted solution, the $\mathrm{Ca}$ and $\mathrm{Mg}$ contents are determined with spectrophotometry of the atomic absorption; $\mathrm{P}$ and $\mathrm{S}$, from spectrophotometry; and $\mathrm{K}$, from flame photometry.

The experiment was conducted in casually delineated blocks, with four treatments and four repetitions. The portions were designated with 4 lines, 5 meters in length, and the two central lines were considered as the useful areas. Four grain sorghum hybrids were evaluated, constituting the different treatments, for each of the different sowing dates. Each date was considered an individual experiment. All features were analyzed relative to the different sowing dates, and afterward, a joint analysis of the data (Tables 3, 4 and 5) was performed. Those data where the medium square ratio of each analysis of variance did not exceed the relation 7:1 were used. When the ratio was higher than this relation, the degrees of liberty were adjusted according to Cochran's methodology (1954).

The " $F$ " test was performed to determine levels of significance of 0.05 and 0.01 for the analysis of variance. When these tests were significant, the averages were compared with the Scott-Knott test at the 0,05 level of probability.

\section{RESULTS AND DISCUSSION}

Analysis of the interaction between hybrids and sowing dates revealed that the $\mathrm{K}$ contents did not vary between hybrids when these were sowed on 17,30 and 41 DAFS. When sown on the first date (26/02), the hybrids $1 \mathrm{G} 282$ and 50A10 showed a higher concentration of $\mathrm{K}$ in the grain. The hybrids 50A10, 50A70 and BUSTER did not show any significant difference in $\mathrm{K}$ content among the sowing dates evaluated.

The hybrids 50A10 and 1G282 showed a higher concentration of this nutrient when sown on the first date, and the hybrid 1G282 showed the same content when 
the sowing occurred on 0 DAFS (Table 6). According to Albuquerque, Camargo and Sousa (2013), who evaluated the macronutrient content in cultivated grain sorghum from different places, the $\mathrm{K}$ was one of the primary macronutrients extracted from the grains, exceeding the $P$ contents and coming in second to N. Furthermore, Marcelo, Corá and Fernandes (2012), on evaluating the macronutrient content absorbed by the sorghum hybrid grains and corn grains, determined that $\mathrm{K}$ was the second-most exported nutrient of the grain, whereas $\mathrm{N}$ was the most exported.

Table 3: Summary of the analysis of the joint variance (average squares) for the content data of macronutrients in the grains $\left(\mathrm{g} \mathrm{kg}^{-1}\right)$ in grain sorghum hybrids from different sowing dates.

\begin{tabular}{cccccccc}
\hline \multirow{2}{*}{ FV } & \multirow{2}{*}{$\mathrm{Gl}$} & \multicolumn{7}{c}{ Average squares } \\
\cline { 3 - 8 } & & $\mathrm{N}$ & $\mathrm{P}$ & \multicolumn{1}{c}{$\mathrm{K}$} & \multicolumn{1}{c}{$\mathrm{Ca}^{1}$} & $\mathrm{Mg}$ & $\mathrm{S}^{1}$ \\
\hline Block (Date) & 12 & 5.6728 & 1.0514 & 0.9141 & 0.0484 & 0.1020 & 0.0401 \\
Hybrids & 3 & $11.4508^{\text {ns }}$ & $0.0780^{\text {ns }}$ & $0.9844^{\text {ns }}$ & $0.0345^{\text {ns }}$ & $0.0404^{\text {ns }}$ & $0.0360^{\text {ns }}$ \\
Date & 3 & $61.3971^{* *}$ & $2.5989^{*}$ & $2.0469^{*}$ & $9.5204^{* *}$ & $0.1496^{\text {ns }}$ & $0.5443^{* *}$ \\
Hybrid*Date & 9 & $5.1073^{\text {ns }}$ & $0.4547^{\text {ns }}$ & $1.8212^{*}$ & $0.0225^{\text {ns }}$ & $0.0725^{\text {ns }}$ & $0.1271^{\text {ns }}$ \\
Residue & 36 & 5.8257 & 0.6054 & 0.6571 & 0.0205 & 0.0909 & 0.0609 \\
\hline CV (\%) & & 12.00 & 23.28 & 22.08 & 4.07 & 16.92 & 34.50 \\
\hline
\end{tabular}

ns; *; ** Not significant, significant at the 0,05 and 0,01 levels of significance according to the $F$ test. ${ }^{1}$ Degrees of liberty adjusted by the method proposed by Cochran (1954).

Table 4: Summary of the analysis of the joint variance (average squares) for the one thousand grain mass (g) and productivity $\left(\mathrm{kg} \mathrm{ha}^{-1}\right)$ of grain sorghum hybrids from different sowing dates.

\begin{tabular}{cccc}
\hline \multirow{2}{*}{ FV } & GL & \multicolumn{2}{c}{ Average squares } \\
\cline { 3 - 4 } & & P1000 & Productivity \\
\hline Block (Date) & 12 & 1.9388 & 266820.2002 \\
Hybrid & 3 & $52.2213^{\text {ns }}$ & $2281211.5625^{* *}$ \\
Date & 3 & $394.5312^{\text {ns }}$ & $4203837.4657^{* *}$ \\
Hybrid*Date & 9 & $11.7798^{* *}$ & $1804363.8777^{* *}$ \\
Residue & 36 & 5.0675 & 317622.3010 \\
\hline CV $(\%)$ & & 9.72 & 12.92 \\
\hline
\end{tabular}

ns; *; ** Not significant, significant at the 0,05 and 0,01 levels of significance according to the $F$ test. ${ }^{1}$ Degrees of liberty adjusted for the method proposed by Cochran (1954).

Table 5: Summary of the analysis of joint variance (average squares) for the average of nutrient exportation (kg $\mathrm{ha}^{-1}$ ) for the grains of grain sorghum hybrids from different sowing dates.

\begin{tabular}{cccccccc}
\hline \multirow{2}{*}{ FV } & \multirow{2}{*}{$\mathrm{Gl}$} & \multicolumn{6}{c}{ Average squares } \\
\cline { 3 - 8 } & & $\mathrm{N}$ & $\mathrm{P}$ & $\mathrm{K}$ & $\mathrm{Ca}$ & $\mathrm{Mg}$ & $\mathrm{S}$ \\
\hline Block (Date) & 12 & 128.8457 & 19.9827 & 18.6765 & 2.1348 & 2.8572 & 1.1106 \\
Hybrid & 3 & $606.9718^{*}$ & $17.9690 \mathrm{~ns}$ & $87.5862^{* *}$ & $31.2744^{* *}$ & $3.8967 \mathrm{~ns}$ & $1.5173 \mathrm{~ns}$ \\
Date & 3 & $3125.0665^{* *}$ & $78.3296^{*}$ & $175.6857^{* *}$ & $154.6600^{* *}$ & $14.3986^{* *}$ & $16.1116^{* *}$ \\
Hybrid*Date & 9 & $811.3124^{* *}$ & $25.0680 \mathrm{~ns}$ & $56.5062^{*}$ & $25.4339^{* *}$ & $5.2566 \mathrm{~ns}$ & $3.6641^{* *}$ \\
Residue & 36 & 167.1238 & 14.2227 & 19.6488 & 3.2043 & 2.8919 & 1.0518 \\
\hline CV (\%) & & 14.79 & 26.00 & 27.48 & 11.75 & 21.97 & 32.30 \\
\hline
\end{tabular}

ns; *; ** Not significant, significant at the 0,05 and 0,01 level of significance according to the $F$ test. 
Table 6: Contents of potassium in hybrid sorghum grain $\left(\mathrm{g} \mathrm{kg}^{-1}\right)$ from four different sowing dates.

\begin{tabular}{ccccc}
\hline \multirow{2}{*}{ Hybrids } & \multicolumn{4}{c}{ Dates } \\
\cline { 2 - 5 } & 0 DAFS & 17 DAFS & $30 \mathrm{DAFS}$ & $41 \mathrm{DAFS}$ \\
\hline $1 \mathrm{G} 282$ & $5.12 \mathrm{Aa}$ & $4.37 \mathrm{aA}$ & $2.62 \mathrm{aB}$ & $3.62 \mathrm{Ab}$ \\
$50 \mathrm{~A} 10$ & $4.62 \mathrm{Aa}$ & $3.75 \mathrm{aA}$ & $3.25 \mathrm{aA}$ & $3.37 \mathrm{Aa}$ \\
$50 \mathrm{~A} 70$ & $2.75 \mathrm{bA}$ & $3.25 \mathrm{aA}$ & $3.87 \mathrm{aA}$ & $3.50 \mathrm{aA}$ \\
BUSTER & $3.75 \mathrm{Ba}$ & $3.87 \mathrm{aA}$ & $3.12 \mathrm{aA}$ & $3.87 \mathrm{Aa}$ \\
\hline
\end{tabular}

Uppercase letters in same row and lowercase letters in same column indicate differences according to the Scott-Knott test at a 0.05 level of significance.

With regard to the contents of $\mathrm{N}$ and $\mathrm{S}$, the absorption of $\mathrm{N}$ and $\mathrm{S}$ for the grain was higher with the earlier sowing dates ( 0 and 17 DAFS) than for the other sowing dates. The later sowing dates likely suffered hydric deficiency, causing lower contents of these nutrients (Table 7).

Table 7: Contents of nitrogen, phosphorus, calcium and sulfur in the grain $\left(\mathrm{g} \mathrm{kg}^{-1}\right)$ from four different sowing dates.

\begin{tabular}{rcccc}
\hline \multirow{2}{*}{ Date } & $\mathrm{N}$ & $\mathrm{P}$ & $\mathrm{Ca}$ & $\mathrm{S}$ \\
\cline { 2 - 5 } & \multicolumn{4}{c}{$\left(\mathrm{g} \mathrm{kg}^{-1}\right)$} \\
\hline 0 DAFS & $21.95 \mathrm{~A}$ & $3.35 \mathrm{~B}$ & $2.88 \mathrm{C}$ & $0.92 \mathrm{~A}$ \\
17 DAFS & $22.74 \mathrm{~A}$ & $3.22 \mathrm{~B}$ & $2.84 \mathrm{C}$ & $0.90 \mathrm{~A}$ \\
30 DAFS & $18.48 \mathrm{~B}$ & $2.99 \mathrm{~B}$ & $4.06 \mathrm{~B}$ & $0.53 \mathrm{~B}$ \\
41 DAFS & $19.78 \mathrm{~B}$ & $3.88 \mathrm{~A}$ & $4.30 \mathrm{~A}$ & $0.62 \mathrm{~B}$ \\
\hline
\end{tabular}

Different uppercase letters in a column indicated differences according to the Scott-Knott test at a 0.05 level of significance.

The contents of $\mathrm{N}$ and $\mathrm{S}$ in the grain sorghum varied from 18.48 to $22.74 \mathrm{~g} \mathrm{~kg}^{-1}$ for the first and 0.53 to $0.92 \mathrm{~g} \mathrm{~kg}^{-1}$ for the second sowing dates. Similar contents of $\mathrm{N}$ and $\mathrm{S}$ were reported by Albuquerque, Camargo and Sousa (2013), who reported approximately $17.00 \mathrm{~g}$ $\mathrm{kg}^{-1} \mathrm{~N}$ and $2.00 \mathrm{~g} \mathrm{~kg}^{-1} \mathrm{~S}$ for the grain sorghum hybrids in their study.

Fince the plants had similar amino acid structural components, their functions were similar, and more $\mathrm{N}$ than $\mathrm{S}$ was required for the plant, which explained the similar behavior that was observed for these two nutrients (Taiz; Zeiger, 2013; Epstein; Bloom, 2006).

For $\mathrm{P}$ and $\mathrm{Ca}$, the observed amounts showed the inverse, where the nutrients were higher in the grain at 41 DAFS than for the other evaluated dates. The $\mathrm{Ca}$ contents were noticeably higher at 30 DAFS than at 0 and 17 DAFS.

Magnesium contents were determined to be approximately $1.78 \mathrm{~g} \mathrm{~kg}^{-1}$. These contents were low, suggesting that this element had little significance when evaluating the value of this nutrient according to the hybrid or the date of sowing.

Regarding the one thousand grain mass $(\mathrm{g})$, the hybrids 1G282 and 50A70 showed lower averages when they were sown on the first date (0 DAFS), whereas there were no significant differences among the averages for the other sowing dates (Table 8).

These values vary between 14.60 and $23.87 \mathrm{~g}$ for $1 \mathrm{G} 282,16.06$ to $26.42 \mathrm{~g}$ for $50 \mathrm{~A} 10$ and 12.86 to 26.89 $\mathrm{g}$ for 50A70. The hybrid BUSTER showed a higher average (29.78 g) with sowing at 30 DAFS. As with the other grain sorghum hybrids, a lower average was observed when the sowing occurred on the first date $(0$ DAFS). When the sowing occurred at 0 and 30 DAFS, the grain characteristics of the hybrids were similar, with BUSTER exhibiting the highest thousand grain mass. For the 17 DAFS sowing, however, there was no significant difference among the hybrids. For the 41 DAFS sowing, the highest masses were the BUSTER, 50A10 and 50A70 hybrids, followed by $1 \mathrm{G} 282$.

According to Silva et al. (2009), evaluations of the one thousand grain mass in the harvests of different grain sorghum hybrids and places in the west-central region revealed on average $17.97 \mathrm{~g}$. With regard to the productivity, they noticed that the 50A10 and 50A70 hybrids did not show significant differences among the sowing dates evaluated. The $1 \mathrm{G} 282$ hybrid showed a lower average productivity only when the sowing occurred at 17 DAFS. In turn, the BUSTER hybrid showed a higher average productivity when sown on the first sowing date (Table 8).

When the hybrids were sown at 0 DAFS, higher productivity was exhibited by the BUSTER hybrid. At 17 DAFS, there was no significant difference among the hybrids. At 30 DAFS, the BUSTER hybrid exhibited the lowest production, whereas the other evaluated hybrids showed higher productivity. When sown at 41 DAFS, the hybrid that was most productive was $1 \mathrm{G} 282$. The average productivity of the grain sorghum hybrids varied from 3178.39 to $6186.10 \mathrm{~kg} \mathrm{ha}^{-1}$, with an experiment average of $3490.05 \mathrm{~kg} \mathrm{ha}^{-1}$.

In their studies, Almeida Filho et al. (2010), Silva et al. (2013) and Silva et al. (2009) observed productivity values that varied from 2267.00 to $5009.00 \mathrm{~kg} \mathrm{ha}^{-1}$ when they evaluated grain sorghum hybrids at harvest. 
Table 8: One thousand grain mass $(\mathrm{g})$ and productivity $\left(\mathrm{kg} \mathrm{ha}^{-1}\right)$ of grain sorghum hybrids from four different dates of sowing.

\begin{tabular}{|c|c|c|c|c|c|}
\hline & \multirow{2}{*}{ Hybrids } & \multicolumn{4}{|c|}{ Date } \\
\hline & & 0 DAFS & 17 DAFS & 30 DAFS & 41 DAFS \\
\hline \multirow{4}{*}{$\begin{array}{l}\text { One thousand } \\
\text { grain mass (g) }\end{array}$} & $1 \mathrm{G} 282$ & $14.60 \mathrm{bB}$ & $23.56 \mathrm{aA}$ & $23.87 \mathrm{bA}$ & $22.39 \mathrm{bA}$ \\
\hline & $50 \mathrm{~A} 10$ & $16.06 \mathrm{bB}$ & $25.47 \mathrm{aA}$ & $25.89 \mathrm{bA}$ & $26.42 \mathrm{aA}$ \\
\hline & $50 A 70$ & $12.86 \mathrm{bB}$ & $24.82 \mathrm{aA}$ & $25.97 \mathrm{bA}$ & $26.89 \mathrm{aA}$ \\
\hline & BUSTER & $19.50 \mathrm{aC}$ & $26.72 \mathrm{aB}$ & $29.78 \mathrm{aA}$ & $25.76 \mathrm{aB}$ \\
\hline \multirow{4}{*}{$\begin{array}{l}\text { Productivity } \\
\left(\mathrm{kg} \mathrm{ha}^{-1}\right)\end{array}$} & $1 \mathrm{G} 282$ & $5075.61 \mathrm{bA}$ & $4233.61 \mathrm{aB}$ & $5029.24 \mathrm{aA}$ & $5247.43 a A$ \\
\hline & $50 A 10$ & 4894.08 bA & $3914.86 \mathrm{aA}$ & $4413.13 \mathrm{aA}$ & $4050.66 \mathrm{bA}$ \\
\hline & $50 A 70$ & $4237.97 \mathrm{bA}$ & $3621.96 \mathrm{aA}$ & $4450.11 \mathrm{aA}$ & $3874.29 \mathrm{bA}$ \\
\hline & BUSTER & $6186.10 \mathrm{aA}$ & $3892.74 \mathrm{aB}$ & $3178.39 \mathrm{bB}$ & $3448.78 \mathrm{bB}$ \\
\hline
\end{tabular}

Uppercase letters in same row and lowercase letters in same column indicate differences according to the Scott-Knott test at a 0.05 level of significance.

Analysis of possible interactions between hybrids and sowing dates indicates that the hybrids 1G282 and 50A10 did not show variation in $\mathrm{N}$ exportation among the sowing dates evaluated. The hybrids 50A70 and BUSTER showed higher exportation of this nutrient when sown on the first sowing date (0 DAFS) (Table 9).

When sown at 0 DAFS, the hybrid that exported the most $\mathrm{N}$ was BUSTER, followed by the others. When sown at 17 DAFS, the hybrids did not show a significant difference in the average exportation of N. For those sown at 30 DAFS, there was no difference in the exportation average $\left(\mathrm{kg} \mathrm{ha}^{-1}\right)$ among the hybrids $1 \mathrm{G} 282,50 \mathrm{~A} 10$ and 50A70, but exportation of $\mathrm{N}$ by BUSTER was different from the other three. When sown at 41 DAFS, the hybrid that showed the higher exportation of N was 1G282. The exportation average of $\mathrm{N}$ varied between 55.02 to 128.22 $\mathrm{kg} \mathrm{ha}^{-1}$.

Similar results were obtained by Calil et al. (2013) when evaluating the productivity and exportation of grain sorghum nutrients in an "agro-forestry" system where the cultivation reached a productivity of $3417.4 \mathrm{~kg} \mathrm{ha}^{-1}$ and showed an average $\mathrm{N}$ exportation of approximately $172.4 \mathrm{~kg} \mathrm{ha}^{-1}$.

Analysis of the $\mathrm{K}$ exportation revealed that the 50A70 hybrid did not show significant differences in the extraction average $\left(\mathrm{kg} \mathrm{ha}^{-1}\right)$ among the sowing dates evaluated. The hybrids $1 \mathrm{G} 282$, 50A10 and BUSTER exported a greater quantity of $\mathrm{K}$ when sown on the first date (Table 9).

For $\mathrm{Ca}$, the BUSTER hybrid showed more exportation when sown on the first date. The other hybrids exported greater quantities of $\mathrm{Ca}$ when the sowing occurred on 30 and 41 DAFS. At 0 DAFS, the BUSTER hybrid was the hybrid that exported the most Ca. For sowing that occurred 17 DAFS, no significant difference was observed among the hybrids for the exported $\mathrm{Ca}$, and the CA content exported for the hybrid grains sown at 41 DAFS was highest for 1G282 (Table 9). The Ca quantity exported varied between 10.57 and $22.43 \mathrm{~kg} \mathrm{ha}^{-1}$.

Related to the S quantity exported, the 50A70 hybrid did not show a difference in the exportation of this nutrient among the evaluated dates. The BUSTER hybrid showed higher average exportation when sown on the first sowing date. The hybrids 50A10 and 1G282 showed higher extraction when sown on 0 and 17 DAFS and lower extraction at 30 and 41 DAFS, except for $1 \mathrm{G} 282$, which showed lower content when sown on 30 DAFS. No significant difference existed among the hybrids when the sowing occurred at 0,17 and 30 DAFS. When the sowing happened at 41 DAFS, the hybrid 1G282 exported the greatest quantity of $\mathrm{S}$. The quantity of exported $\mathrm{S}$ by the hybrids varied between 1.35 and $5.29 \mathrm{~kg} \mathrm{ha}^{-1}$ of $\mathrm{S}$.

The average contents of nutrient exportation $(\mathrm{kg}$ $\mathrm{ha}^{-1}$ ) were similar to those reported by Calil et al. (2013) for grain sorghum cultivation, which were $172.40 \mathrm{~kg} \mathrm{ha}^{-1}$ $\mathrm{N}, 24.10 \mathrm{~kg} \mathrm{ha}^{-1} \mathrm{P}, 54.20 \mathrm{~kg} \mathrm{ha}^{-1} \mathrm{~K}, 5.30 \mathrm{~kg} \mathrm{ha}^{-1} \mathrm{Ca}, 7.30$ $\mathrm{kg} \mathrm{ha}^{-1} \mathrm{Mg}$, and $2.30 \mathrm{~kg} \mathrm{ha}^{-1} \mathrm{~S}$.

The content of $\mathrm{P}$ and $\mathrm{Mg}$ that was extracted from the grains varied among the sowing dates. Exportation of $\mathrm{P}$ and $\mathrm{Mg}$ in hybrids sown at 0 and 41 DAFS was higher than in those sown at 17 and 30 DAFS (Table 10). The average $P$ extracted varied from 12.42 to $16.57 \mathrm{~kg} \mathrm{ha}^{-1}$, and was related to the average $\mathrm{Mg}$ extracted, which showed similar variability from 6.75 to $8.95 \mathrm{~kg} \mathrm{ha}^{-1}$. 
Table 9: Exportation ( $\mathrm{kg} \mathrm{ha}^{-1}$ ) of nitrogen, potassium, calcium and sulfur in grain sorghum hybrids from different sowing dates.

\begin{tabular}{|c|c|c|c|c|c|}
\hline \multirow{2}{*}{ Nutrients } & \multirow{2}{*}{ Hybrids } & \multicolumn{4}{|c|}{ Date } \\
\hline & & 0 DAFS & 17 DAFS & 30 DAFS & 41 DAFS \\
\hline \multirow{4}{*}{$\mathrm{N}$} & $1 G 282$ & $98.72 \mathrm{bA}$ & $89.79 \mathrm{aA}$ & $84.85 \mathrm{aA}$ & $101.22 \mathrm{aA}$ \\
\hline & $50 \mathrm{~A} 10$ & $103.13 \mathrm{bA}$ & $95.41 \mathrm{aA}$ & $85.97 \mathrm{aA}$ & $82.37 \mathrm{bA}$ \\
\hline & $50 A 70$ & 99.46 bA & $74.83 \mathrm{aB}$ & $80.03 \mathrm{aB}$ & $70.83 \mathrm{bB}$ \\
\hline & BUSTER & $128.22 \mathrm{aA}$ & $85.61 \mathrm{aB}$ & $55.02 \mathrm{bc}$ & $63.20 \mathrm{bC}$ \\
\hline \multirow{4}{*}{ K } & $1 \mathrm{G} 282$ & $25.98 \mathrm{aA}$ & $18.69 \mathrm{aB}$ & $13.03 \mathrm{aB}$ & $19.05 \mathrm{aB}$ \\
\hline & $50 A 10$ & $22.73 \mathrm{aA}$ & $14.66 \mathrm{aB}$ & $14.24 \mathrm{aB}$ & $13.69 \mathrm{aB}$ \\
\hline & 50A70 & $11.83 \mathrm{bA}$ & $11.66 \mathrm{aA}$ & $17.27 \mathrm{aA}$ & $13.56 \mathrm{aA}$ \\
\hline & BUSTER & $23.52 \mathrm{aA}$ & $14.70 \mathrm{aB}$ & $10.03 \mathrm{aB}$ & $13.39 \mathrm{aB}$ \\
\hline \multirow{4}{*}{$\mathrm{Ca}$} & $1 \mathrm{G} 282$ & 14.56 bB & $11.71 \mathrm{aC}$ & $20.31 \mathrm{aA}$ & $22.43 \mathrm{aA}$ \\
\hline & $50 \mathrm{~A} 10$ & $14.30 \mathrm{bB}$ & $10.98 \mathrm{aC}$ & $17.47 \mathrm{aA}$ & $17.29 \mathrm{bA}$ \\
\hline & 50A70 & $12.04 \mathrm{bB}$ & $10.57 \mathrm{aB}$ & $18.80 \mathrm{aA}$ & $16.76 \mathrm{bA}$ \\
\hline & BUSTER & $17.80 \mathrm{aA}$ & $10.97 \mathrm{aC}$ & $12.74 b c$ & $14.93 \mathrm{bB}$ \\
\hline \multirow{4}{*}{$S$} & $1 \mathrm{G} 282$ & $3.99 \mathrm{aA}$ & $3.82 \mathrm{aA}$ & $1.98 \mathrm{aB}$ & $4.66 \mathrm{aA}$ \\
\hline & $50 \mathrm{~A} 10$ & $4.74 \mathrm{aA}$ & $3.43 \mathrm{aA}$ & $2.11 \mathrm{aB}$ & $2.13 \mathrm{bB}$ \\
\hline & 50A70 & $3.86 \mathrm{aA}$ & $3.19 \mathrm{aA}$ & $3.34 \mathrm{aA}$ & $1.93 \mathrm{bA}$ \\
\hline & BUSTER & $5.29 \mathrm{aA}$ & $3.23 \mathrm{aB}$ & $1.35 \mathrm{aC}$ & $1.72 \mathrm{bc}$ \\
\hline
\end{tabular}

Uppercase letters in same row and lowercase letters in same column indicate differences according to the Scott-Knott test at a 0.05 level of significance.

Table 10: Phosphorus and magnesium exportation by hybrid grain sorghums $\left(\mathrm{g} \mathrm{kg}^{-1}\right)$ from different sowing dates.

\begin{tabular}{ccc}
\hline \multirow{2}{*}{ Date } & $\mathrm{P}$ & $\mathrm{Mg}$ \\
\cline { 2 - 3 } & \multicolumn{2}{c}{$\left(\mathrm{g} \mathrm{kg}^{-1}\right)$} \\
\hline 0 DAFS & $16.57 \mathrm{~A}$ & $8.95 \mathrm{~A}$ \\
17 DAFS & $12.42 \mathrm{~B}$ & $6.75 \mathrm{~B}$ \\
30 DAFS & $12.76 \mathrm{~B}$ & $7.30 \mathrm{~B}$ \\
41 DAFS & $16.25 \mathrm{~A}$ & $7.96 \mathrm{~A}$ \\
\hline
\end{tabular}

Uppercase letters in same column indicate differences according to the Scott-Knott test at a 0.05 level of significance.

The plant nutritional status is determined by the quantity of nutrients extracted. The quantity extracted depends on the productivity achieved and the nutrient contents in the aboveground portion of the plant and the grains (Fornasieri Filho; Fornasieri, 2009).

Fertilization recommendations for the plants should consider the expected productivity such that the application of nutrients is in the right quantities, which makes the knowledge about the nutritional extraction by the sorghum during the production of
1 ton of grains important (Santos et al., 2014). The extract information reported should be used as a reference when planning soil fertility management to achieve the full productive potential of the hybrids. Thus, in this work, the average accumulation of macronutrients for the production of $1 \mathrm{t} \mathrm{ha}^{-1}$ of grain sorghum is reported (Table 11).

Table 11: Accumulation of macronutrients for the production of $1 \mathrm{t} \mathrm{ha}^{-1}$ of grain sorghum.

\begin{tabular}{cccccc}
\hline $\mathrm{N}$ & $\mathrm{P}$ & $\mathrm{K}$ & $\mathrm{Ca}$ & $\mathrm{Mg}$ & $\mathrm{S}$ \\
\hline$-\mathbf{-}$ & $-\mathbf{-}$ \\
$\mathbf{2 0 . 0 5}$ & 3.33 & 3.70 & 3.49 & 1.77 & 0.72 \\
\hline
\end{tabular}

Fornasieri Filho and Fornasieri (2009) showed values of average accumulation of nutrients $\left(\mathrm{kg} \mathrm{t}^{-1}\right)$ ranging from 17.10 to $18.6 \mathrm{~kg} \mathrm{~N}, 5.90$ to $8.80 \mathrm{~kg} \mathrm{P}, 4.2$ to $4.9 \mathrm{~kg}$ $\mathrm{K}, 0.60$ to $0.80 \mathrm{~kg} \mathrm{Ca}, 1.40$ to $1.50 \mathrm{~kg} \mathrm{Mg}$ and 2.00 to $2.01 \mathrm{~kg} \mathrm{~S}$. 


\section{CONCLUSIONS}

The productivity of grain sorghum hybrids vary as a function of sowing date, as well as the one thousand grain mass. The average exportation of macronutrients for the grain sorghums is as follows in decreasing order: $(\mathrm{N}$ $>\mathrm{K}>\mathrm{P}>\mathrm{Ca}>\mathrm{Mg}>\mathrm{S}$ ) and the average values of these macronutrient accumulation for the production of one ton of grains are $20.05 \mathrm{~kg} \mathrm{~N}, 3.33 \mathrm{~kg} \mathrm{P}, 3.70 \mathrm{~kg} \mathrm{~K}, 3.49 \mathrm{~kg} \mathrm{Ca}$, $1.77 \mathrm{~kg} \mathrm{Mg}$ and $0.72 \mathrm{~kg} \mathrm{~S}$.

\section{ACKNOWLEDGEMENTS}

The authors thank FAPEMIG, CNPq and CAPES for the financial support.

\section{REFERENCES}

ALBUQUeRQUE, C. J. B.; CAMARGO, R. de; SOUZA, M. F. de. Extração de macronutrientes no sorgo granífero em diferentes arranjos de plantas. Revista Brasileira de Milho e Sorgo. 12(1):10-20, 2013.

ALBUQUERQUE, C. J. B. et al. Espaçamento e densidade de semeadura para cultivares de sorgo granífero no semiárido. Bragantia. 70(2):278-285, 2011.

ALMEIDA FILHO, J. E. de. et al. Avaliação agronômica de híbridos de sorgo granífero em diferentes regiões produtoras do Brasil. Revista Brasileira de Milho e Sorgo. 13(1):82-95, 2014.

ALMEIDA FILHO, J. E. de. et al. Desempenho agronômico e estabilidade fenotípica de híbridos de sorgo granífero. Revista Brasileira de Milho e Sorgo. 9(1):54-64, 2010.

CALIL, F. N. et al. Biomassa e nutrientes em sistemas agrossilvicultural no extremo sul do Brasil. Ecologia e nutrição florestal. 1(2):80-88, 2013.

COCHRAN, W. G. The combination of estimates from different experiments. Biometrics. 10:101-129, 1954.

EMPRESA BRASILEIRA DE PESQUISA AGROPECUÁRIA EMBRAPA. Manual de análises químicas de solos, plantas e fertilizantes. 2.ed. Brasília, Distrito Federal: Embrapa informações tecnológicas, 2009, 627p.

EPSTEIN, E. E.; BLOOM, A. J. Nutrição mineral de plantas: Princípios e perspectivas. 2. ed. Londrina, 2006, 403p.
FORNASIERI FILHO, D.; FORNASIERI, J. L. Manual da cultura do sorgo. Jaboticabal: Funep, 2009, 202p.

LEAL, S. T. et al. Análise econômica da produção de sorgo na safrinha com diferentes fontes de nitrogênio em cobertura. Revista Brasileira de Milho e Sorgo. 12(2):8591, 2013.

MALAVOlTA, E.; VITTI, G. C.; OLIVEIRA, S. A. Avaliação do estado nutricional das plantas: princípios e aplicações. 2. ed. Piracicaba, SP: Associação Brasileira para Pesquisa da Potassa e do Fosfato, 1997. 319p.

MARIN, F. R. et al. Perda de produtividade potencial da cultura do sorgo no Estado de São Paulo. Bragantia. 65(1):157162, 2006.

MARCELO, A. V.; CORÁ, J. E.; FERNANDES, C. Sequências de culturas em sistema de semeadura direta I - produção de matérias seca e acúmulo de nutrientes. Revista Brasileira de Ciências do Solo. 36:1553-1567, 2012.

PARRELLA, R. A. da C. et al. Cultivares In: BOREM, A.; PIMENTEL, L. D.; PARRELLA, R. A. C. (eds). Sorgo do plantio à colheita. Viçosa, MG: UFV, 2014 p.169-187.

PRADO, H.; JORGE, J. A.; MENK, J. R. F. Levantamento pedológico detalhado e caracterização físico-hídrico dos solos da estação experimental de agronomia de Votuporanga (SP). Campinas: IAC, 1999. 24p. Boletim científico, 42.

SANTOS, F. C. et al. Correção do solo e adubação na cultura do sorgo. Informe Agropecuário. 35(278):76-88, 2014.

SILVA, A. G. et al. Avaliação de cultivares de sorgo granífero no Sudoeste do Estado de Goiás. Pesquisa Agropecuária Tropical. 39(2):168 -174, 2009.

SILVA, K. J. et al. Seleção de híbridos de sorgo granífero cultivados no verão em três localidades. Revista Brasileira de Milho e Sorgo. 12(1):44-53, 2013.

TAIZ, L.; ZEIGER, E. Fisiologia vegetal. 5.ed. Porto Alegre: Artmed, 2013. 918p.

TOLK, J. A.; HOWELL, T. A.; MILLER, F. R. Yield component analysis of grain sorghum grown under water stress. Field Crops Research. 145:44-51, 2013.

VASCONCELLOS, C. A. et al. Resíduos de sorgo e a mineralização do nitrogênio em Latossolo Vermelho fase cerrado. Scientia Agricola. 58(2):373-379, 2001. 